\title{
Response of Different Seed Rate on the Productivity of Hybrid Fodder Sorghum (Sugar graze) in South East Rajasthan
}

\author{
Harphool Meena*, R.S. Narolia, Pratap Singh, P.K.P. Meena and B.L. Kumhar \\ AICRP on Irrigation Water Management, Agricultural Research Station, \\ Ummedganj Farm Agriculture University, Kota-324001, Rajasthan, India \\ *Corresponding author
}

\begin{tabular}{|c|c|}
\hline & A B S T R A C T \\
\hline Keywords & \multirow{4}{*}{$\begin{array}{l}\text { A field experiment was conducted during two consecutive years from } 2014 \\
\text { and } 2015 \text { at Agricultural Research Station, Kota, Significantly higher green } \\
\text { fodder yield ( } 907 \mathrm{q} / \mathrm{ha}) \text { and dry fodder yield ( } 245 \mathrm{q} / \mathrm{ha}) \text { were observed with } \\
\text { sowing of Sugargraze by } 9.5 \mathrm{~kg} \text { seed/ha over local chari sowing by } 10.0 \mathrm{~kg} \\
\text { seed/ha green fodder yield }(668 \mathrm{q} / \mathrm{ha}) \text { and dry fodder yield }(168 \mathrm{q} / \mathrm{ha}) \text {. } \\
\text { However, it was found at par with sowing of Sugargraze by } 7.5 \mathrm{~kg} \text { seed/ha } \\
\text { green fodder yield ( } 896 \mathrm{q} / \mathrm{ha}) \text { and dry fodder yield }(242 \mathrm{q} / \mathrm{ha}) .\end{array}$} \\
\hline $\begin{array}{l}\text { Sugargraze, } \\
\text { Seed rate and } \\
\text { Fodder yield. }\end{array}$ & \\
\hline Article Info & \\
\hline $\begin{array}{l}\text { Accepted: } \\
\text { 19 April } 2017 \\
\text { Available Online: } \\
10 \text { May } 2017\end{array}$ & \\
\hline
\end{tabular}

\section{Introduction}

Sorghum [Sorghum bicolor (Linn.) Moench] is an important crop in the world, used for food (as grain or sorghum molasses), fodder, the production of alcoholic beverages and biofuels. Most varieties are drought and heat tolerant, and are especially important in arid regions, where the grain is one of the staple foods for poor and rural people. It is an important food and fodder crop grown in India, and among cereals, it is the fourth most important crop after rice, wheat and maize (Dehinwal et al., 2016).

Sorghum grain is used as staple food by millions of people and is grown for grain in southern and central states of India, whereas in northern states of the country (Punjab, Haryana, Uttar Pradesh, Rajasthan, etc.) it is mainly grown as fodder during summer and kharif seasons as a single as well as multicut crop. Among forage crops, forage sorghum could be a strategic option because of the crop's xerophilic characteristics, adaptation potential, quick growing habit, good ratoon ability, palatability, digestibility and wide range of potential uses as green fodder, dry roughage, hay and silage (Kumar and Chaplot, 2015).

Among crop management practices seeding densities or plant population greatly affect crop growth and then finally grain yield. Therefore seeding density is a key factor in assessing the flexibility and yielding ability of cultivars. Both over and substandard plant population is the major cause of low yield (Jan et al., 2000). 
Optimum seed rate plays an important role in contributing to the high yield because in case of thick plant population, most plants remain sterile, easily attacked by diseases as compared to normal population (Robert and Singh, 1981). To obtain high quality preserved forage (silage or hay), harvest sugargraze at knee height stage. For silage, let plants wilt prior to ensiling and lower moisture content will reduce effluent losses from silage. In the India, two to three subsequent harvests are possible. To stimulate recovery growth, fertilize with $\mathrm{N}$ immediately following the initial harvest (Smith et al., 2005).

\section{Materials and Methods}

Field experiment was conducted during two consecutive years from 2014 and 2015 at Agricultural Research Station, Kota. $\mathrm{T}_{1}$ : Sugargraze (seed rate $3.5 \mathrm{~kg} / \mathrm{ha}$ ), $\mathrm{T}_{2}$ : Sugargraze (seed rate $5.5 \mathrm{~kg} / \mathrm{ha}$ ), $\mathrm{T}_{3}$ : Sugargraze (seed rate $7.5 \mathrm{~kg} / \mathrm{ha}$ ), $\mathrm{T}_{4}$ : Sugargraze (seed rate9.5 kg/ha), $\mathrm{T}_{5}$ : Sugargraze (seed rate11.5 kg/ha) andT : Local chari (seed rate $10.0 \mathrm{~kg} / \mathrm{ha}$ ). The experimental field was well prepared by two ploughing followed by harrowing and cultivator and one planking for uniform leveling, etc were performed for sowing of sorghum crop. The experiment was laid-out in RBD with four replications and six treatments. The recommended dose of nitrogen, phosphorus and potash i.e. $125 \mathrm{~kg}$ $\mathrm{N} / \mathrm{ha}, 60 \mathrm{~kg} \mathrm{P}_{2} \mathrm{O}_{5} /$ ha and $60 \mathrm{~kg} \mathrm{~K}_{2} \mathrm{O}$ /ha was given in the form of urea, di-ammonium phosphate (DAP) and muriate of potash (MOP). Full dose of DAP and MOP and half $\mathrm{N}$ were drilled just before sowing and remaining half-N was applied in two split doses as per recommendation.

The bulk density, $\mathrm{pH}$ and cation exchange capacity of these soils varies between 1.30-
$1.60 \mathrm{Mg} / \mathrm{m}^{3}, 7.75-8.50$ and $30-40 \mathrm{Cmol} / \mathrm{kg}$, respectively. The soils of the region are poor in organic carbon $(0.50 \pm 0.08)$ and available nitrogen $(275 \pm 5 \mathrm{~kg} / \mathrm{ha})$ but are low to medium in available $\mathrm{P}_{2} \mathrm{O}_{5}(24.2 \pm 1.0 \mathrm{~kg} / \mathrm{ha})$ and medium to high in available $\mathrm{K}_{2} \mathrm{O}(290 \pm 8$ $\mathrm{kg} / \mathrm{ha})$.

\section{Results and Discussion}

\section{Plant population}

The plant population and growth parameters of sugargraze were significantly influenced by sowing of different seed rate (Table 1). Pooled data of two years showed that the significantly higher plant population (491886/ha) of sugargraze was recorded with the sowing of 11.5 $\mathrm{kg}$ seed/ha which was significantly superior over rest of the treatments.

\section{$I^{\text {st }}$ cutting}

Two years pooled data indicated that(Table 1) the maximum plant height $(154 \mathrm{~cm})$, leaf weight/plant $(93.75 \mathrm{~g})$ and stem weight/plant $(280.65 \mathrm{~g})$ were recorded with the sowing of sugargraze by $3.5 \mathrm{~kg}$ seed/ha over local chari plant height $(132 \mathrm{~cm})$, leaf weight/plant $(70.6 \mathrm{~g})$ and stem weight/plant (214.15 g). However, it was found at par with sowing of sugargraze 5.5 and $7.5 \mathrm{~kg}$ seed/ha. Pooled data of two years shows that the fodder yield was significantly influenced by sowing of different seed rate of sugar graze (Table 1). Sowing of sugargraze with $9.5 \mathrm{~kg}$ seed/ha were observed maximum green fodder yield (568q/ha), dry fodder yield (153q/ha) and dry matter $(26.86 \%)$ but it was found at par with the sowing of sugargraze $7.5 \mathrm{~kg}$ seed/ha over local chari sowing with $10.0 \mathrm{~kg}$ seed/ha green fodder yield $(413 \mathrm{q} / \mathrm{ha})$, dry fodder yield $(109 q /$ ha) and dry matter $(25.80 \%)$ table 3 . These results are in close proximity with those of Dehinwal et al., (2016), Smith et al., (2005) and Jan et al., (2000). 
Table.1 Effect of different seed rate on plant population, growth and fodder yield of sugargraze (Ist cutting)

\begin{tabular}{|c|c|c|c|c|c|c|c|c|c|c|c|c|c|c|c|c|c|c|}
\hline \multirow[t]{2}{*}{ Treatments } & \multirow{2}{*}{$\begin{array}{l}\text { Plant } \\
2014\end{array}$} & \multicolumn{2}{|c|}{$\begin{array}{r}\text { population } \\
\text { (thousand/ha) }\end{array}$} & \multicolumn{3}{|c|}{ Plant height $(\mathrm{cm})$} & \multicolumn{3}{|c|}{$\begin{array}{c}\text { Weight of leaves/ plant } \\
(\mathrm{g})\end{array}$} & \multicolumn{3}{|c|}{$\begin{array}{c}\text { Weight of stem/plant } \\
(\mathrm{g})\end{array}$} & \multicolumn{3}{|c|}{$\begin{array}{ccc}\text { Green } & \text { fodder } & \text { yield } \\
& (q / h a) & \end{array}$} & \multicolumn{3}{|c|}{ Dry fodder yield (q) } \\
\hline & & 2015 & Pooled & 2014 & 2015 & Pooled & 2014 & 2015 & Pooled & 2014 & 2015 & Pooled & 2014 & 2015 & Pooled & 2014 & 2015 & Poc \\
\hline $\begin{array}{l}\text { T1: Sugargraze (seed } \\
\text { rate } 3.5 \mathrm{~kg} / \mathrm{ha} \text { ) }\end{array}$ & 156667 & 158400 & 157534 & 153.2 & 153.7 & 153.50 & 93.7 & 93.8 & 93.75 & 280.0 & 281.3 & 280.65 & 386 & 388 & 387 & 107 & 109 & \\
\hline $\begin{array}{l}\text { T2: Sugargraze (seed } \\
\text { rate } 5.5 \mathrm{~kg} / \mathrm{ha} \text { ) }\end{array}$ & 245313 & 247375 & 246344 & 152.2 & 152.5 & 152.38 & 92.7 & 92.8 & 92.75 & 279.0 & 280.0 & 279.50 & 424 & 427 & 426 & 113 & 115 & \\
\hline $\begin{array}{l}\text { T3: Sugargraze (seed } \\
\text { rate } 7.5 \mathrm{~kg} / \mathrm{ha} \text { ) }\end{array}$ & 328750 & 330750 & 329750 & 150.7 & 151.2 & 151.00 & 92.4 & 92.5 & 92.45 & 277.8 & 279.3 & 278.55 & 558 & 562 & 560 & 150 & 151 & \\
\hline $\begin{array}{l}\text { T4: Sugargraze (seed } \\
\text { rate } 9.5 \mathrm{~kg} / \mathrm{ha} \text { ) }\end{array}$ & 408854 & 410900 & 409877 & 141.2 & 143.2 & 142.25 & 91.3 & 91.4 & 91.35 & 275.3 & 276.0 & 275.65 & 566 & 569 & 568 & 152 & 153 & \\
\hline $\begin{array}{l}\text { T5: Sugargraze (seed } \\
\text { rate } 11.5 \mathrm{~kg} / \mathrm{ha} \text { ) }\end{array}$ & 490729 & 493042 & 491886 & 135.5 & 136.5 & 136.03 & 73.5 & 73.7 & 73.6 & 252.5 & 253.8 & 253.15 & 516 & 519 & 518 & 135 & 137 & \\
\hline $\begin{array}{l}\text { T6: Local variety (seed } \\
\text { rate } 10.0 \mathrm{~kg} / \mathrm{ha} \text { ) }\end{array}$ & 417188 & 419025 & 418107 & 131.2 & 132.7 & 131.99 & 70.6 & 70.6 & 70.6 & 213.4 & 214.9 & 214.15 & 411 & 414 & 413 & 106 & 111 & \\
\hline $\mathrm{SEm} \pm$ & 1102 & 1088 & 1007 & 1.0 & 1.2 & 1.0 & 0.74 & 0.73 & 0.67 & 1.23 & 1.31 & 1.16 & 3.88 & 4.03 & 3.63 & 1.11 & 1.09 & 1 \\
\hline $\mathrm{CD}$ at $5 \%$ & 3318 & 3276 & 2909 & 3.2 & 3.4 & 2.9 & 2.22 & 2.19 & 1.93 & 3.70 & 3.93 & 3.35 & 11.70 & 12.14 & 10.48 & 3.34 & 3.29 & 2 \\
\hline
\end{tabular}

Table.2 Effect of different seed rate on plant growth and fodder yield of sugargraze (IInd cutting)

\begin{tabular}{|c|c|c|c|c|c|c|c|c|c|c|c|c|c|c|c|}
\hline \multirow[t]{2}{*}{ Treatments } & \multicolumn{3}{|c|}{ Plant height $(\mathrm{cm})$} & \multicolumn{3}{|c|}{$\begin{array}{c}\text { Weight of leaves/ plant } \\
\text { (g) }\end{array}$} & \multicolumn{3}{|c|}{$\begin{array}{c}\text { Weight of stem/ plant } \\
(\mathrm{g})\end{array}$} & \multicolumn{3}{|c|}{$\begin{array}{cc}\text { Green fodder yield } \\
(q / h a)\end{array}$} & \multicolumn{3}{|c|}{ Dry fodder yield (q/ha) } \\
\hline & 2014 & 2015 & Pooled & 2014 & 2015 & Pooled & 2014 & 2015 & Pooled & 2014 & 2015 & Pooled & 2014 & 2015 & Pooled \\
\hline T1: Sugargraze (seed rate $3.5 \mathrm{~kg} / \mathrm{ha}$ ) & 133 & 134 & 134 & 66.08 & 66.30 & 66.19 & 159.8 & 161.3 & 160.55 & 247 & 250 & 249 & 62 & 64 & 63 \\
\hline T2: Sugargraze (seed rate $5.5 \mathrm{~kg} / \mathrm{ha}$ ) & 132 & 133 & 133 & 65.75 & 66.08 & 65.92 & 157.3 & 158.5 & 157.9 & 263 & 266 & 265 & 68 & 69 & 69 \\
\hline T3: Sugargraze (seed rate $7.5 \mathrm{~kg} / \mathrm{ha}$ ) & 131 & 132 & 132 & 64.75 & 65.05 & 64.90 & 156.0 & 157.3 & 156.65 & 334 & 337 & 336 & 90 & 91 & 91 \\
\hline T4: Sugargraze (seed rate $9.5 \mathrm{~kg} / \mathrm{ha}$ ) & 125 & 126 & 126 & 62.00 & 62.23 & 62.12 & 155.6 & 157.1 & 156.35 & 338 & 340 & 339 & 91 & 93 & 92 \\
\hline T5: Sugargraze (seed rate $11.5 \mathrm{~kg} / \mathrm{ha}$ ) & 120 & 121 & 121 & 55.50 & 55.68 & 55.59 & 135.3 & 136.8 & 136.05 & 265 & 268 & 267 & 67 & 68 & 68 \\
\hline T6: Local variety (seed rate $10.0 \mathrm{~kg} / \mathrm{ha}$ ) & 117 & 118 & 118 & 51.75 & 52.02 & 51.89 & 118.3 & 120.3 & 119.3 & 253 & 256 & 255 & 57 & 60 & 59 \\
\hline $\mathrm{SEm} \pm$ & 0.67 & 0.84 & 0.69 & 1.01 & 0.98 & 0.91 & 1.28 & 1.65 & 1.34 & 3.00 & 2.87 & 2.70 & 0.58 & 0.71 & 0.59 \\
\hline $\mathrm{CD}$ at $5 \%$ & 2.02 & 2.52 & 2.00 & 3.05 & 2.96 & 2.64 & 3.86 & 4.98 & 3.89 & 9.05 & 8.66 & 7.79 & 1.74 & 2.13 & 1.71 \\
\hline
\end{tabular}


Table.3 Effect of different seed rate on dry matter (\%) and total green and dry fodder yield of sugargraze (Ist cutting and IInd cutting)

\begin{tabular}{|c|c|c|c|c|c|c|c|c|c|c|c|c|}
\hline \multirow[t]{2}{*}{ Treatments } & \multicolumn{3}{|c|}{$\begin{array}{c}\text { Dry matter (\%) } \\
I^{\text {st }} \text { cutting }\end{array}$} & \multicolumn{3}{|c|}{$\begin{array}{c}\text { Dry matter (\%) } \\
\text { II }^{\text {nd }} \text { cutting }\end{array}$} & \multicolumn{3}{|c|}{ Green fodder yield (q/ha) } & \multicolumn{3}{|c|}{ Dry fodder yield (q/ha) } \\
\hline & 2014 & 2015 & Pooled & 2014 & 2015 & Pooled & $\mathrm{I}^{\mathrm{st}}$ cutting & II $^{\text {nd }}$ cutting & Total & $\begin{array}{c}\text { Ist } \\
\text { cutting }\end{array}$ & $\begin{array}{c}\text { II }^{\text {nd }} \\
\text { cutting }\end{array}$ & Tot \\
\hline T1: Sugargraze (seed rate $3.5 \mathrm{~kg} / \mathrm{ha}$ ) & 27.72 & 27.73 & 27.73 & 25.10 & 25.12 & 25.11 & 387 & 249 & 636 & 108 & 63 & 17 \\
\hline T2: Sugargraze (seed rate $5.5 \mathrm{~kg} / \mathrm{ha}$ ) & 26.65 & 26.67 & 26.66 & 25.85 & 25.86 & 25.86 & 426 & 265 & 691 & 114 & 69 & 18 \\
\hline T3: Sugargraze (seed rate $7.5 \mathrm{~kg} / \mathrm{ha}$ ) & 26.88 & 26.90 & 26.89 & 26.94 & 26.96 & 26.95 & 560 & 336 & 896 & 151 & 91 & 24 \\
\hline T4: Sugargraze (seed rate $9.5 \mathrm{~kg} / \mathrm{ha}$ ) & 26.85 & 26.86 & 26.86 & 26.92 & 26.94 & 26.93 & 568 & 339 & 907 & 153 & 92 & 24 \\
\hline T5: Sugargraze (seed rate $11.5 \mathrm{~kg} / \mathrm{ha}$ ) & 26.16 & 26.18 & 26.17 & 25.28 & 25.29 & 25.29 & 518 & 267 & 785 & 136 & 68 & 20 \\
\hline T6: Local variety (seed rate $10.0 \mathrm{~kg} / \mathrm{ha}$ ) & 25.79 & 25.81 & 25.80 & 22.52 & 22.57 & 22.55 & 413 & 255 & 668 & 109 & 59 & 16 \\
\hline SEm \pm & 0.14 & 0.14 & 0.12 & 0.20 & 0.20 & 0.18 & 3.63 & 2.70 & - & 1.01 & 0.59 & \\
\hline CD at $5 \%$ & 0.42 & 0.42 & 0.37 & 0.59 & 0.60 & 0.53 & 10.48 & 7.79 & - & 2.92 & 1.71 & \\
\hline
\end{tabular}

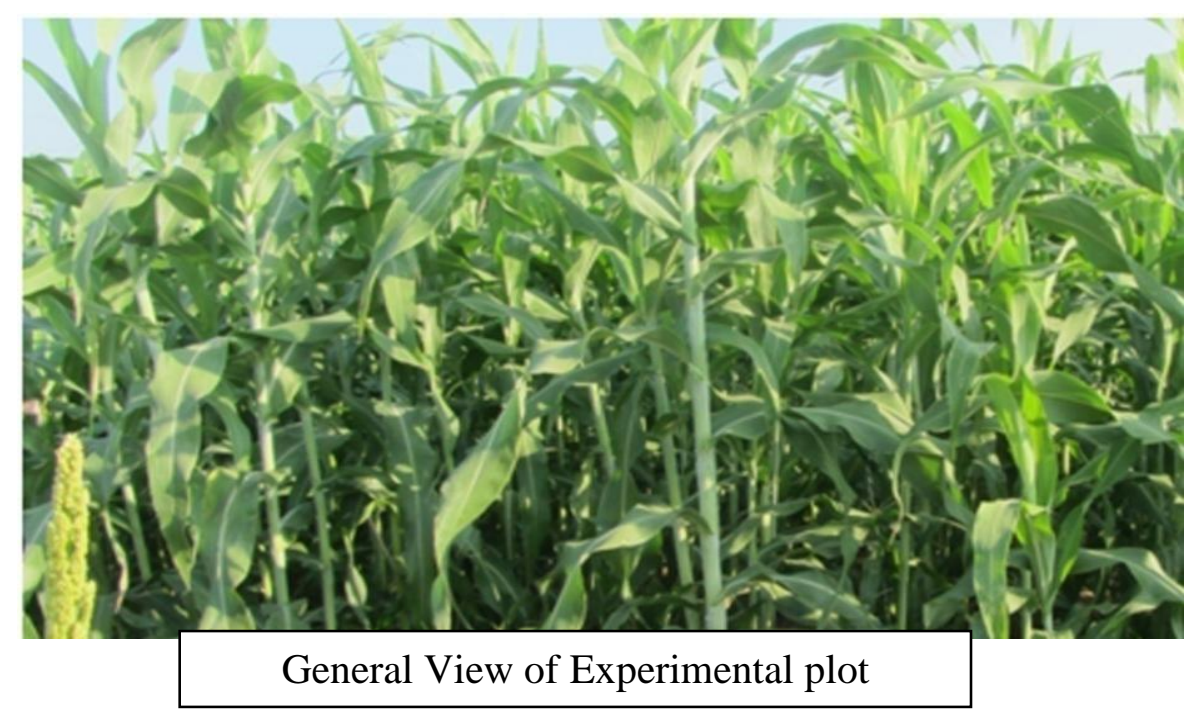




\section{II $^{\text {nd }}$ cutting}

During II $^{\text {nd }}$ cutting plant growth was significantly influenced (Table 2) by sowing of different seed rate of sugargraze. The maximum plant height $(134 \mathrm{~cm})$, leaf weight/ plant (66.19g) and stem weight/ plant $(160.55 \mathrm{~g})$ of sugargraze were recorded with the sowing of $3.5 \mathrm{~kg}$ seed/ha of sugargraze over local chari plant height $(118 \mathrm{~cm})$, leaf weight/ plant $(51.89 \mathrm{~g})$ and stem weight/ plant $(119.3 \mathrm{~g})$ sowing with $10 \mathrm{~kg}$ seed/ha. However, it was found at par with sowing of sugargraze 5.5 and $7.5 \mathrm{~kg}$ seed/ha, respectively. Fodder yield of sugargraze was significantly influenced by sowing with different seed rates. The maximum green fodder yield (339 q/ha), dry fodder yield (92q/ha) (Table 2) and dry matter (26.93\%) were observed under sowing of sugargraze $9.5 \mathrm{~kg} \mathrm{seed} / \mathrm{ha}$ but it was found at par with the sowing of sugargraze $7.5 \mathrm{~kg}$ seed/ha green fodder yield (336q/ha), dry fodder yield (91q/ha) and dry matter $(26.95 \%)$ over rest of treatments (Table 3). These results are in close proximity with those of Satpal et al., 2016; Kumar and Chaplot.

In conclusion, significantly higher green fodder yield (907 q/ha) and dry fodder yield
(245 q/ha) were observed with sowing of sugargraze by $9.5 \mathrm{~kg}$ seed/ha over local chari sowing by $10.0 \mathrm{~kg}$ seed/ha green fodder yield (668 q/ha) and dry fodder yield (168 q/ha). However, it was found at par with sowing of sugargraze by $7.5 \mathrm{~kg}$ seed/ha green fodder yield (896 q/ha) and dry fodder yield (242 $\mathrm{q} / \mathrm{ha})$.

\section{References}

Dehinwal, A.K., S.K. Pahujaand M. Shafiqurrahaman. 2016. Environmental effect on sorghum fodder yield and its related traits. Forage Res., 42: pp.189194.

Jan, A., Kaleem, S.A., Taj, F.H. and Khan, H. 2000. Response of mungbean cultivars to different seeding densities at dry land conditions. Pak. J. Biol. Sci., 3: 203032.

Kumar, D. and P.C. Chaplot. 2015. Performance of multicut forage sorghum genotypes to fertility levels. Forage Res., 41: 199-201.

Robert, W. and Singh, K. 1981. Food Grain, A Text Book of Punjab Agriculture, Civil and Ministry Gazette, Lahore. 287.

\section{How to cite this article:}

Harphool Meena, R.S. Narolia, Pratap Singh, P.K.P. Meena and Kumhar, B.L. 2017. Response of Different Seed Rate on the Productivity of Hybrid Fodder Sorghum (Sugar graze) in South East Rajasthan. Int.J.Curr.Microbiol.App.Sci. 6(5): 1978-1982.

doi: https://doi.org/10.20546/ijcmas.2017.605.221 